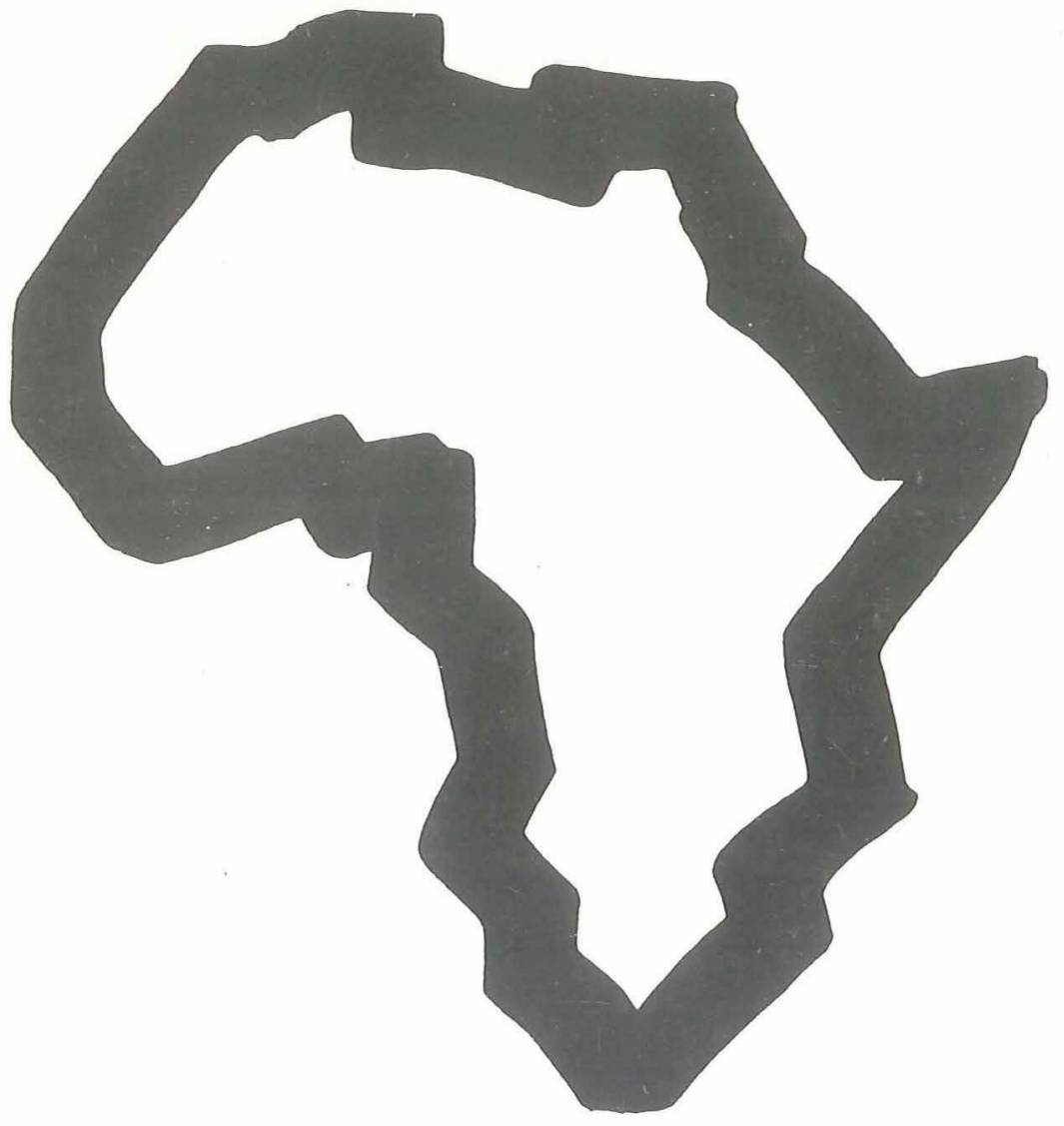

\title{
NAMIBIA
}

AND

\section{THE NORDIC COUNTRIES}

Scandinavian Institute of African Studies, Uppsala 

NAMIBIA AND THE NORDIC COUNTRIES

by

H-O Sano

J Koponen

A Tostensen

R Stanbridge

The Scandinavian Institute of African Studies Uppsala 1981 
ISBN 91-7106-198-3

Motala Grafiska

Motala 1981 


\section{CONTENTS}

Preface

Introduction

Denmark by Hans-0tto Sano

Finland by Juhani Koponen

Norway by Arne Tostensen

Sweden by Roland Stanbridge 

PREFACE

Since the establishment in 1962 of the Scandinavian Institute of African Studies, it has followed events in Southern Africa and has been active in disseminating information about the region through seminars and publications. In 1981 the situation in Namibia has been highlighted by intensification of the war as well as by diplomatic activities. In spite of temporary setbacks recently it can be anticipated that the liberation struggle in combination with diplomatic initiatives will result in an independent Namibia within this decade.

In order to illuminate the role played by the Nordic countries in the liberation of Namibia the Scandinavian Institute of African Studies organized a seminar called "Namibia and the Nordic Countries" in March 1981. This booklet is a by-product of the seminar. Its aim is to outline the official positions of the Nordic governments (except Iceland) as regards Namibia. The emphasis is on the debate in the United Nations and on assistance towards the liberation of Namibia. Non-governmental assistance is also included as we 11 as available information on trade between the Nordic countries and Namibia.

Due to the special relationship between Finland and Namibia (i.e. Finnish missionary activity in Namibia since 1870) the section on Finland is more elaborate than those of the other Nordic countries. The historical background to the relations between Finland and $\mathrm{Na}-$ mibia as well as the various Finnish initiatives in the UN are outlined.

The booklet has been written by research fellows at the Scandinavian Institute of African Studies. It is hoped that it will serve as a brief introduction to relations between the Nordic countries and Namibia.

Uppsala October 1981

Michael Ståhl

Director 

NAMIBIA, THE UNITED NATIONS AND THE NORDIC COUNTRIES

Since the end of World War II the status of the territory of South West Africa (as it was then termed) has been a point of dispute between South Africa and the United Nations. The dispute began in 1946 when South Africa, which in 1919 had been given mandatory authority over the territory by the League of Nations, questioned the right of the UN to replace the League as the ultimate authority over Namibia. Hence, South Africa refused to enter into a trusteeship agreement with the UN similar to those established for other mandated areas. The dispute was brought before the International Court of Justice in the Hague which on three occasions during the 1950 's ruled on the issue, advising that South Africa was neither legally obliged to enter into a trusteeship agreement with the UN, nor competent to alter the legal status of the territory unilatera11y.

In 1960 Ethiopia and Liberia, then the only two African members of the UN and former members of the League, requested the Court to rule on the system of apartheid introduced by South Africa in Namibia, claiming it to be in violation of her mandatory obligations. In 1966 the Court resolved not to rule on the substance of the matter since it held that neither Ethiopia nor Liberia had any right to raise the issue before the court.

In two ways the 1966 decision of the Court marked a turning point in the dispute over Namibia. The first part of the 1960s had seen the liberation of several African states from colonial rule, and in Namibia the ruling of the Court had been anticipated with rising hopes and expectations. SWAPO, which had been formed in 1960, now saw no other possibility than to turn to armed struggle. In the UN, the procedural decision of the Court and the subsequent launching of armed struggle by SWAPO convinced a majority of the member states that the world organisation itself had to initiate action to take the issue further.

In November 1966 the General Assembly adopted Resolution 2145 terminating the South African mandate over South West Africa. Hence, the UN assumed responsibility over the territory which in 1968 was renamed Namibia. The Council for Namibia was established in 1967 and given formal jurisdiction over the country. As its executive arm the office of a Commissioner for Namibia was instituted.

With the adoption of Resolution 2145 a new development began in the constitutional history of Namibia. From the point of view of the Namibian people living within the borders of the territory, however, the resolution was of little practical value. Unable to enforce South African withdrawal from the country, the influence and authority exerted by the UN remained extra-territorial, and even today Namibia remains a de facto colony ruled by the Republic of South Africa. 
In 1969 the UN Security Council endorsed Resolution 2145 of 1966, but no further developments took place until 1970. On Finnish initiative the International Court of Justice was once more requested by the UN for a ruling on the dispute, and in 1971 the Court held that the South African occupation was illegal and endorsed UN Resolution 2145.

The statement of the Court opened the possibility for new initiatives by the UN. Secretary General Kurt Waldheim started negotiations with the South African regime in 1972, on the invitation of the Security Council. But the talks soon proved futile and were discontinued in 1973 as the South African government refused to cooperate in establishing the necessary conditions for independence in Namibia. The delaying tactics employed by the South African government and the cautious course adopted by the Security Council and its Western members provoked especially the Third World countries in the General Assembly. This led to sharp criticism of the negotiations during 1972-1973 and to Western economic interests in South Africa and $\mathrm{Na}-$ mibia being pin-pointed as an obstacle to the finding of quick solutions. In line with these feelings, SWAPO was recognized as the authentic representative of the Namibian people by the General Assembly in 1973. This resolution is the reason for South Africa's accusation of UN partiality.

The coup of 1974 in Portugal and the subsequent liberation of Angola and Mozambique made the issue of Namibia more acute, and when the UN convened during the summer of 1975 African member states urged the Security Council to adopt a resolution declaring the South African occupation a threat to international peace and security. According to the Charter of the UN this would open up the possibility of sanctions against South Africa. A mandatory arms embargo was specifically aimed at by the African proposal. The resolution was vetoed by France, Great Britain and the United States.

Nevertheless, pressure from the Third World countries prompted the Western countries to take action, partially to avoid a deep split between the Security Council and the General Assembly. In 1976 the Security Council unanimously agreed on Resolution 385 condemning South African illegal occupation of Namibia, racial discrimination and military raids into neighbouring countries from Namibia. Most important, the resolution spoke in favour of the Namibian people deciding upon their own future, through free elections under UN supervision and control. South Africa was, however, in the process of preparing internal ethnically based elections according to the Turnhalle Conference Draft Constitution of 1977. This constitution provided for eleven ethnic governments, each separately elected by the respective ethnic groups. Each ethnic government would then appoint delegates to a central government. At this stage the five Western members of the Security Council, i.e. Canada, Great Britain, France, United States and West Germany, intervened and entered into negotiations with South Africa on independence for Namibia according to Resolution 385 (1976). While negotiating, South Africa however continued its policy of setting up a compliant government in Namibia. A further step by the South African regime which indicated its lack 
of sincerity was the annexation of Walvis Bay in September 1977 and its subsequent inclusion into South Africa.

During 1978 negotiations continued between the UN Secretary General, his special representative Martti Ahtisaari, the Western contact group, SWAPO and South Africa. A plan for free elections was accepted by SWAPO. Even the South African government seemed to accept the principles of the plan. But in September it reversed its position declaring that it could not agree with the time-table and that it would proceed with holding internal elections based on the Turnhalle Conference Draft Constitution by the end of the year without UN supervision.

The UN plan for elections was endorsed by the Security Council as Resolution 435, * and though the South African announcement regarding internal elections dealt a severe blow to the prestige and credibility of the Western contact group in particular, which had been responsible for the principal part of the negotiations, further sanctions against South Africa were not applied. After the internal elections the Secretary General and his special representative sought during 1979 and 1980 to remove the obstacles to implementation of Resolutions 385 and 435, among other ways by seeking to create a demilitarized zone between Namibia and Angola. These initiatives culminated in the UN Pre-Implementation Meeting held in Geneva in January 1981, which ended in failure.

* Resolution 435 (1978):

The Security Council decided to establish under its authority a United Nations Transition Assistance Group (UNTAG) under the direction of the Secretary General's Special Representative for a period up to 12 months to ensure free and fair elections under UN supervision and control in Namibia.

The UN Plan would be carried out in three stages, namely

a) Cessation of all hostile acts by all parties and the withdrawal, restriction and demobilization of the various armed forces.

b) Conduct of free and fair elections to the constituent assembly, for which the pre-conditions include the repeal of discriminatory or restrictive laws, regulation or administrative measures, the release of political prisoners and detainees and voluntary return of exiles, the establishment of effective monitoring by the United Nations and an adequate period for electoral campaigning.

c) The formulation and adoption of a constitution for Namibia by the constituent assembly to be followed by the entry into force of the constitution and the consequent achievement of independence of Namibia. 
The Debate on Namibia in the General Assembly in September 1981

Subsequent to the breakdown of the UN Pre-Implementation Meeting on Namibia in Geneva in January 1981 and following the Security Council veto in April 1981 by France, Great Britain and the USA on sanctions against South Africa, a number of new initiatives have been taken in the hope of bringing the situation out of its present deadlock. A proposal by African member states calling for a special emergency session of the General Assembly on the Namibia question was accepted by an overwhelming majority. All the Nordic countries voted in the affirmative. In the course of the session itself in September 1981 the debate culminated in a resolution calling for, inter alia, support for SWAPO and the frontline states, including military assistance, and for the imposition, individually or collectively, of comprehensive sanctions against South Africa. The resolution also rejected the "...manoeuvres by certain members of the Western contact group aimed at undermining the international consensus embodied in Security Council resolution $435 \ldots$. The resolution was carried by a vote of 117 in favour, none against, and 25 abstentions. All the Western states abstained, including the Nordic ones.

Recognizing that an impasse has been reached the Western contact group has continued its diplomatic efforts outside the UN framework. Hoping to soften the intransigent position of the South African government they seem to be making a number of concessions on issues about which South Africa has previously been adamant.

At the time of writing the exact contents of the proposal resulting from these talks are not known. Nevertheless the main points under discussion include the following:

a) pre-election constitution guaranteeing the future of minority (i.e. white) parties and groups in an independent Namibia;

b) post-independence negotiations for a separate agreement on the status of Walvis Bay;

c) guarantees by SWAPO that, if elected, it would not a1low Namibia to be used by "terrorists" for attacks against South Africa;

d) pre-election peace-keeping force of Western rather than UN troops;

e) withdrawal of Cuban troops from Angola as part of a package, though not necessarily as a pre-condition for negotiations.

Al1 of these points are at variance with the provisions of Security Council Resolution 435. They are clearly designed to appease the South African government in order to lure it to the negotiating, table once again.

The Nordic Countries and Namibia

What have been the policies of the Nordic countries? The Nordic countries have supported the view that peaceful solutions to the 
conflict should be sought, i.e. they have supported the policies of conciliation embarked upon by the large Western countries, and they have emphatica11y declined to endorse armed struggle by SWAPO as a legitimate part of the UN policy as proposed by the Third World countries since 1976 .

The rejection of armed struggle as a means of finding a solution to the conflict has been the main point of difference between the Nordic policies and those of the Third World countries. But apart from this, they have, together with Holland, expressed considerable understanding and support for the views forwarded by the Third World countries in the General Assembly. In this sense they have, especially in the early stages of the conflict, sought to act as mediators between North and South in order to obtain the greatest possible unity behind the resolutions adopted. This was, for instance, the case in 1971 when the Nordic delegations went into consultation with the Afro-Asiatic group in order to modify the formulation of the resolution on the general situation in Namibia before passing it (a resolution regularly passed every year expressing condemnation of the South African presence in Namibia and commenting on the current state of negotiations). It was also the case in 1966 , when Denmark went into lengthy negotiations on the formulation of Resolution 2145 with the result that only France, Great Britain and Malawi abstained from voting.

During the 1970s, however, the policy of mediation became increasingly meaningless as every attempt to negotiate with South Africa failed and as the Third World countries in general adopted a more radical stance. During this period the Nordic countries were content to give statements on their own political position. They have mostly abstained from attempts to influence the parties in the conflict directly, confining themselves to playing an active role in matters of humanitarian and development assistance. Finland played a leading role in initiating programmes of assistance, including both the UN Fund for Namibia of 1970 and the Nationhood Programme of 1976, in order to provide funds for the preparation of independence in Namibia.

During the middle of the 1970 s the Nordic countries also became increasingly open to a policy of sanctions against the apartheid regime as a means to speed up the process of liberation. Sweden and Norway were particularly outspoken in this respect, supporting an arms embargo already in 1975. Denmark and Finland were more hesitant on the issue, though a common Nordic agreement and support for an arms embargo was reached in 1976.

Although the Nordic policies in the UN are regularly discussed at the half-yearly meetings of Nordic Ministers of Foreign Affairs and although the wish to act in Nordic unity has been strong since World War II, elaboration of a common policy is not a must, and especially in the second part of the 1970 s differences, however small, in the policies of the various countries are easily seen. 
It is often stressed by foreign office officials that the policies of their governments in the UN, for instance, are not subject to any restrictions due to foreign alignments or affiliations the country is part of - be it Nato, the EEC or other commitments. This might, at least in the case of the Nordic countries and their relations with a relatively distant country such as Namibia, be the truth; but the fact remains that Sweden which is non-aligned with a long tradition of neutrality, is also the country which has been able to pursue the most radical line of policy among the Nordic countries, at least when it comes to sanctions against South Africa. Sweden has been an ardent advocate of sanctions in the UN and taken some action unilaterally. Although it was agreed as part of the joint Nordic programme of action in March 1978 to discourage or prohibit investments in South Africa, Sweden is the only Nordic country to have taken legal measures to that effect, whereas the other Nordic countries have taken nonlegal action as a follow-up to the March 1978 programme.

Successive Swedish governments have held the view that South Africa has used the negotiations with the Western powers or the UN Secretary General to uphold the status quo and that the pressure on South Africa should be increased even while the negotiations were going on. In contrast, Denmark, which is a member of both Nato and the EEC, has pursued a comparatively soft and cautious policy in respect of Namibia and South Africa, more akin to the compliant course adopted by the Western countries in general. With respect to sanctions, Denmark has kept a low profile. In 1978 it abstained from voting together with the EEC-countries (contrary to the other Nordic countries) on a resolution recommending a trade, oil and extended arms embargo against South Africa. In fact, since the middle of the $1970 \mathrm{~s}$ Denmark has acted both as a member of the Nordic countries and as a member of the group of 9 - the EEC-countries - but has in her voting pattern followed the EEC-countries rather than the Nordic countries.

One should, however, be careful to note that these differences only reflect nuances and not serious cleavages of policy among the Nordic countries. Neither should international commitments be seen as the sole explanation of the differences. Finland's special relations with Namibia, which are treated in the section on Finland, have already been mentioned; but resourcefulness might also explain some of the differences. For a long period, Sweden has been outstanding in her assistance to SWAPO and to Namibia-related activities, as is evident from the table overleaf, and this might also form part of the background to her clear stand against the apartheid regime. A large purse maked a controversial stand more easy to follow up.

The Nordic countries have consistently opposed the position of the majority of the General Assembly that the UN should endorse armed struggle as part of its policy. Even if they have sometimes voted for resolutions speaking in favour of armed struggle, they have immediately reserved themselves on the issue in explanations of vote. With respect to the status of SWAPO, however, they have not pursued a similar consistent line of policy. They have voted for several resolutions recognizing SWAPO as the sole, authentic representative of the Namibian people, except for Denmark, which has been careful to 
underline that other groupings were also part of the struggle and that the process of liberation must be a democratic one (see also section on Denmark). Finland, Norway and Sweden have not submitted similar statements, but when they themselves have voiced their policy, they have refrained from employing the formulation of the General Assembly speaking of SWAPO as the true or most representative spokesman of the Namibian people. It is hardly a coincidence that these countries have not attached the same importance to this matter as Denmark. It follows the general pattern of policy of the various countries. However, when the officials of the various Ministries of Foreign Affairs met in early 1981 to agree on a common statement on the Namibian issue, they chose a formulation close to the Danish position, stating that "no party enjoying popular support should be excluded from a political solution through free and fair elections. SWAPO is such a party and must be part of any solution in Namibia". By agreeing on an official Nordic position on this particular point the role attributed to SWAPO has been defined within a narrower framework than earlier, and it is hardly likely that the policies of the various governments will differ much from the official Nordic position in the future.

In a joint explanatory note to their vote at the special emergency session of the General Assembly on Namibia in September 1981 the Nordic countries reaffirmed their support for Security Council Resolution 435, but regretted that they could not vote in favour of the present resolution on the grounds that it contained a number of paragraphs to which the Nordic countries on numerous previous occasions have taken exception. They hold that armed struggle is unacceptable as a means of conflict resolution, and that, as a matter of UN procedure, only the Security Council may impose sanctions binding on all member states.

\section{NORDIC ASSISTANCE TO NAMIBIA}

After the Second World War more than 900 UN meetings have been held and more than 70 resolutions passed on the Namibian issue without conditions changing fundamentally. One might say that the greatest achievement of this vast investment of human energy has been to imm prove the climate for assistance to the Namibian people. This took place especially during the 1970s. The UN Fund for Namibia and the Nationhood Programme have already been mentioned. In addition, the UN Institute for Namibia in Lusaka was started in 1976 with the aim of training public servants and administrators for an independent Namibia. Similarly, other funds and programmes have come into being during this decade, and a number of international organisations have started to channel funds to Namibian refugees and to SWAPO.

The Nordic countries gradually increased their assistance to Namibia, in particular, and to the victims of apartheid oppression in southern Africa in general during the 1970s. Starting from almost nil in the early 1970 s, it now reaches a total of appr. $22 \mathrm{mill}$. \$. However, it 
should be noted that this amount includes allocations for territories other than Namibia, since some of the allocations are given in a lump sum to southern Africa in general and later administratively distributed among the various recipients. The UN Trust Fund and the UN Educational and Training Programme thus cover the whole of southern Africa. Similarly, non-governmental organisations like WUS or IDAF are distributing assistance to several of the countries in southern Africa. Some of the Nordic allocations, however, are directly linked to Namibia, i.e., the UN Institute, the General Account and the Nationhood Programme, and funds are allocated directly to SWAPO, as can be seen from the table.

Table 1.

Assistance by the Nordic governments to Namibia and to organisations assisting Namibia in 1980 (in US\$1,000)

\begin{tabular}{|c|c|c|c|c|}
\hline & Denmark & Finland & Norway & $\begin{array}{l}\text { Sweden } \\
(1980 / 81)\end{array}$ \\
\hline $\begin{array}{l}\text { UN Trust Fund for } \\
\text { southern Africa }\end{array}$ & 226 & 92 & 308 & 528 \\
\hline $\begin{array}{l}\text { UN Educational and } \\
\text { Training Programme }\end{array}$ & 415 & 92 & 809 & 367 \\
\hline $\begin{array}{l}\text { UN Fund for Namibia } \\
\text { General Account }\end{array}$ & - & 39 & 50 & - \\
\hline Nationhood Programme & - & 524 & 957 & - \\
\hline $\begin{array}{l}\text { UN Institute for } \\
\text { Namibia }\end{array}$ & 282 & 131 & 193 & 642 \\
\hline $\begin{array}{l}\text { World University } \\
\text { Service (WUS) }\end{array}$ & 794 & - & 68 & 1,720 \\
\hline $\begin{array}{l}\text { International Defence } \\
\text { and Aid Fund (IDAF) }\end{array}$ & 415 & 29 & 488 & 2,064 \\
\hline Directly to SWAPO & - & 481 & 1,541 & 7,568 \\
\hline Others & 116 & 162 & 328 & - \\
\hline Total & 2,288 & 1,550 & 4,742 & 12,889 \\
\hline
\end{tabular}

Sources: Danida, Finnida, Sida and respective Ministries of Foreign Affairs

Exchange rates ultimo 1980: 1 US $\$=6.02$ Danish kroner, 5.19 Norwegian kroner, 4.36 Swedish kronor and 3.82 Finnish marks.

Among these programmes the Nordic countries have contributed especially to the Nationhood Programme and to the UN Institute, while the General Account of the UN Fund reserving funds for the general costs of the UN administration of Namibia has on 1 y received 1 imited 
amounts from Finland and Norway (and in 1981/82 also from Sweden). The Nationhood Programme which started on a rather ambitious scale ran, however, into administrative difficulties. After some delays in channelling funds to the programme, contributions from a11 Nordic countries are now forthcoming.

The determination of al1 the Nordic governments to contribute to the cause of a free Namibia has been confirmed by the recent elaboration of a common Nordic administrative plan of assistance to an independent Namibia. The Finnish Ministry of Foreign Affairs will be administratively in charge of the programme, and the plan envisages the establishment of a common Nordic bureau of assistance in Namibia working in cooperation with representatives of the free government. The aid given will, in principle, not be tied to the buying of commodities and services from the Nordic countries.

Hence, even if nuances in the Nordic policies often appear, common action still takes place. Since 1976 the officials of the various ministries of foreign affairs working with southern Africa have met several times a year for consultations and discussions. Common action and energetic policies are also needed, however. Even if the Nordic countries have had to give up part of their active mediating role in the UN due to the deepening of the conflict and have played their biggest role in influencing the political process indirectly through support for programmes of assistance, there is still scope for political action. The center of gravity of the conflict lies now in a triangle between SWAPO and the majority of the General Assembly supporting SWAPO, the dominant Western powers of the Security Council, and South Africa. The Nordic countries still have a role to play in seeking to move Western policy in a progressive direction. The conflict over Namibia has been a fact since the end of World War II; and the armed struggle for liberation, which started as early as 1966, has been intensified over the years. To apply extra pressure on South Africa, not least by imposing more effective sanctions, seems to be one important way for the Nordic countries to contribute to the ending of the struggle. 

DENMARK

\section{The Official Position}

The viceconsular representation of the Danish government in Windhoek was closed down in 1970. Since then there have been no contacts between the Danish government and the illegal regime in Namibia. Over the last years, however, SWAPO delegations have payed a number of visits to Denmark. With the growth of the Danish assistance to the victims of the conflict in Namibia the relations with the 1iberation movement have been intensified. The delegations have met with representatives of the government and the foreign affairs administration. The meetings have not only been confined to problems of assistance, but have also centered around political issues.

In 1 ine with the constitutional status of Namibia the Danish governments have considered the problems ensuing from South African occupation a matter for the UN, and accordingly the Danish policy has been voiced within that forum. In the UN there has been some confusion as to the political role and authority attributed to SWAPO. Regarding it as the sole and authentic representative of the Namibian people, the majority of the members of the General Assembly have been willing to confer to SWAPO a role almost equal to the one played by ordinary members. The Danish governments, however, together with the other Nordic countries have held that SWAPO was only the most representative spokesman of the Namibian people stressing that the UN still exerts the formal responsibility over the country. In 1 ine with these tenets, Denmark has been careful to underline the role played by other organisations and parties in Namibia such as SWANU, stressing that the process of liberation must be a democratic one with al1 the groups and organisations in Namibia given a right to voice their feelings.

On the whole, among the Nordic countries, Denmark has pursued the most cautious policy with respect to Namibia. The Danish governments have been reluctant to impose a policy of sanctions against South Africa, and generally, the Danish governments have been more persistent in adhering to the principles of the UN Charter and procedures, which impose constraints on candid support for the liberation struggle and a hard-line policy against South Africa. For instance, in 1976, contrary to the rest of the Nordic countries, but in line with the EEC-countries, the Danish representatives in the UN opposed a resolution recognizing SWAPO as an observateur in the UN for the reason that the UN was an organisation of states. The adherence to the rules and procedures may of course be based on a due respect for the UN Charter and has certainly made the Danish position appear more consistent than any of its Nordic counterparts on issues like the latter one; but undoubtedly there is also a political reason for this stance.

The right wing parties of the Danish parliament have always looked upon support for and aid to liberation movements with scepticism, 
if not dissaprova1, particularly when such movements have taken an anti-Western stand. A cautious position in the UN has therefor been necessary in order to preserve a united stand on the Namibian question in the Danish Parliament.

\section{Assistance to the 1iberation of Namibia}

\section{Governmental assistance}

Since the middle of the $1960^{\prime}$ s funds have been allocated for the victims of oppossion in southern Africa. Between 1964/65 and 1971 funds rose from 0.225 million Danish kroner to 1.5 million Dkr. Since $1972 / 73$ with the intensificasion of the liberation war in Southern Africa, liberation movements have been recognized as receivers of funds. The right wing parties only reluctantly agreed on this conditioning that the assistance was not given as a means of political support, but as a means of channelling aid to the victims of the conflicts. Hence, since $1972 / 73$ assistance has risen from 6.5 million Dkr. to 14.3 million Dkr in 1978, 25 million in 1979, and 35 milion in 1980 and 1981 respectively.

Popularly, this particular kind of assistance has been termed "antiapartheid-spending". Officially it is called "Spending to oppressed Groups or Peoples for Humanitarian and Educational Assistance through International Organisations and Liberation Movements". Hence, funds are explicitely allocated for humanitarian purposes and most of them through various international organisations. Funds reaching various liberation movements are tied to the buying of specific commodities and are never given in cash.

Of total spending, 15.450 mil1. Dkr. in 1979, 14.000 million in 1980 and 19.540 million in 1981 went to Namibia-related activities, the reason for the lower amount in 1980 being the liberation of Zimbabwe drawing extra funds to among other things the resettlement of refugees.

The assistance is either given directly to the various UN programmes or is given to non-governmental organisations which support Namibian activities. Among the former funds have been allocated for the UN Institute of Namibia and for the Nationhood Programme. A11ocations for the Nationhood Programme was resumed in 1981 after a two year pause caused by the reorganisation of the programme. The programme has now been allocated a lump sum of 2.500 million Dkr. together with the Namibia Institute to be distributed among the two by the UN.

Among the non-governmental organisations mainly World University Service and in 1981 also Lutheran World Federation included Namibian activities in their work and were allocated major amounts of the anti-apartheid spending. Moreover, in 1981 World University Service has administrated some of the funds earlier allocated for the Inter- 
national University Exchange Fund after it became known that IUEF was infiltrated by a South African spy. A detailed table of the distribution of total Danish anti-apartheid spending in 1979, 1980 and 1981 is given in the appendix at the end of the booklet.

Non-Official assistance

Apart from official assistance aid has also been channeled through various solidarity groups which regularly organise public collections for victims of the Namibian struggle. During 1980 "T $\phi j$ Til Afrika" (Clothes for Africa) sent nearly 27 tonnes of clothes and 5-10 $\mathrm{m}^{3}$ of medicines to the Namibian refugee camps. Moreover, printing machinery worth Danish $\mathrm{kr} .40,000$ was granted to SWAPO.

Another organisation "U-landshjelp fra Folk til Folk" (Development Aid from People to People) which started its Namibian activities during the latter part of 1980 has in the course of the last year sent 155 tonnes of clothes, 8 lorries, 1 landrover and 11 watercarrying carts, 90 sewing machines, 50 office machines of various kinds, 25 tonnes of school material, 10 tonnes of hospital equipment, 12 tonnes of $\mathrm{fish}$ meal, 1,400 shoes and 150,000 $\mathrm{Dkr}$ for the establishment of a kindergarden in the refugee camp in Kwanza Sul in Angola. Moreover, 2 volunteers were recently sent to Kwanza Sul, and UFF is presently trying to establish a vocational school for Namibian skilled workers in Denmark.

Trade

Table 2

Dennark's Trade with Namibia 1970-1980 (Imports c.i.f. and exports f.o.b.) in $1,000 \mathrm{Dkr}$

\begin{tabular}{|c|c|c|}
\hline Year & Imports & Exports \\
\hline 1970 & 8,000 & 710 \\
\hline 1971 & 7,636 & 700 \\
\hline 1972 & 3,897 & 592 \\
\hline 1975 & 1,771 & 348 \\
\hline 1976 & 33 & 910 \\
\hline 1977 & - & 235 \\
\hline 1978 & 15 & 582 \\
\hline 1979 & 20 & 748 \\
\hline $1980^{*}$ & - & 584 \\
\hline
\end{tabular}

Source: Monthly Bulletin of Foreign Trade, 1970-72, 1975-1980

* January-October 1980 
There are no restrictions on Trade with Namibia; but as in the case of South Africa, the government has encouraged industry to stop trade with Namibia. Likewise, in line with the Nordic programme of action of March 1978, the governmet has indicated that further investments in Nanibia should not take place; but still the government has not given the policies legal content as in Sweden, where the programme of action was followed up by restricitions on new investments.

It is hardly the exhortations of the government, however, which have caused imports and exports to decline throughout the 1970's. Imports consisted mainly of "non-ixon metallics" which constituted more than $75 \%$ of total imports in the early 70's, and disappeared towards the middle of the decade before the government tried to intervene. In 1976 imports were made up of only wood and cork, and were almost negligible.

Swakara pelts have played a dominant role in the protests against trade with Namibia. Large-scale imports of raw pelts, however, were only concentrated to a few years just before the middle of the $70^{\prime} \mathrm{s}$, i.e. 1973 and 1974, exactly when the Namibian trade statistics were included in the South African according to EEC procedures, which were later abandoned. Hence, total imports from both Namibia and South Africa reached the order of a magnitude of $56 \mathrm{mil1.} \mathrm{Dkr} \mathrm{in}$ 1973 with pelts being the dominant commodity according to one source*, whereas it was almost negligibel before and after these years. In 1970 raw pelts to the value of $115,000 \mathrm{Dkr}$ were imported, while the figure declined to 3,000 Dkr in 1971. Since 1975 imports of raw pelts form Namibia have stopped.

This does not imply, however, that imports of swakara fur coats have stopped. Since the middle of the seventies London instead of Copenhagen has been one of the main centres of imports of raw pelts. The pelts are processed in London or in West Germany and reach the Scandinavian markets only after processing. In the statistics they are now registered as import from London or West Germany, whereas the basic country of origin is Namibia. (Cf. a note on the trade statistics at the end of the booklet.

Danish exports to Namibia have consisted mainly of dairy and machinery products, but throughout the period they have been negligible. Whereas 8 Danish companies have investments in South Africa there is no documentation that any of these have extended their investments to Namibia. However, the commodities produced in South Africa will enter into the general circulation between South Africa and Namibia. It is thus possible to find commodities produced under a Danish trade mark in Namibia.

* See article by Knud Vilby in Kontakt no. 1 1974/75, p. 28 


\section{Conclusions}

In conclusion, the policy of the variuos Danish governments has been one of clear protest against South African occupation of Namibia. Economic relations with Namibia have always been negligible and have even declined over the last years. Political relations with the illegal regime have been severed, and a number of positive contacts have been established with SWAPO. Over the last years assistance to the victims of the Namibian struggle has been growing steadily a1though the Danish governments, unlike the other Nordic countries, have preferred not to give assistance to SWAPO directly.

However, Danish foreign policy in general has a stronger pro-western leaning than that of for instance Sweden and Finland. The fact that the Danish governments have entered in to a cooperation with the EEC-countries on the Namibian issue can only strenghten this position, and might explain why Denmark generally has pusued a somewhat softer policy on the issue than her Nordic counterparts. This, at least, has been the case with respect to the status of SWAPO and with respect to the sanctions against South Africa where Denmark has voted together with the EEC-countries rather than with the Nordic countries.

Concerning the role of sanctions against South Africa the Danish governments have encouraged the industries of the country to sever contacts with South Africa, but recently the government has implicitly approved of steady increases in coal imports from South Africa. It is worth noting that the state itself thus sets this example for her industries. Attempts to isolate South Africa, and the policies of supporting the liberation of Namibia are closely linked. Denmark, like the rest of the Nordic countries, has a role to play in pursuing consistent policies on both of these issues. 
Appendix: Official Assistance from the Nordic Countries towards the Liberation of Namibia

DENMARK

Table 3

Tota1 Anti-Apartheid-Spending 1979, 1980 and 1981

(1 000 Danish kroner)

\begin{tabular}{|c|c|c|c|}
\hline & 1979 & 1980 & 1981 \\
\hline UN Trust Fund for southern Africa & 1,400 & 1,600 & 2,000 \\
\hline UN Educational and Training Programme & 1,800 & 2,500 & 3,000 \\
\hline UN Institute for Namibia & 1,500 & 1,700 & 2.500 \\
\hline Nationhood Programme & - & - & \\
\hline $\begin{array}{l}\text { UN High Commissioner for Refugees } \\
\text { Zimbabwe }\end{array}$ & - & 5,000 & - \\
\hline $\begin{array}{l}\text { Int. Defence and Aid Fund } \\
\text { Zimbabwe }\end{array}$ & 2,100 & 2,500 & 2,700 \\
\hline $\begin{array}{l}\text { Int. University Exchange Fund } \\
\text { funds distributed by wUS } \\
\text { funds distributed by SIUA } \\
\text { funds distributed by Africa } \\
\text { Educational Trust }\end{array}$ & $\begin{array}{c}6,755 \\
- \\
-\end{array}$ & 4,500 & $\begin{array}{l}- \\
3,800 \\
-\end{array}$ \\
\hline $\begin{array}{l}\text { World University Service (wUS) } \\
\text { South Africa and Zimbabwe } \\
\text { Namibia }\end{array}$ & $\begin{array}{l}2,470 \\
2,615\end{array}$ & $\begin{array}{l}1,780 \\
3,000\end{array}$ & $\begin{array}{l}1,960 \\
4,940\end{array}$ \\
\hline $\begin{array}{l}\text { World Council of Churches } \\
\text { South Africa and Zimbabwe }\end{array}$ & 1,880 & 1,675 & 4,000 \\
\hline $\begin{array}{l}\text { Lutheran World Federation } \\
\text { South Africa and Zimbabwe } \\
\text { Namibia }\end{array}$ & $\begin{array}{l}2,110 \\
1,380\end{array}$ & $\begin{array}{r}7,060 \\
700\end{array}$ & $\begin{array}{l}4,300 \\
2,300\end{array}$ \\
\hline $\begin{array}{l}\text { Danish Federation of Trade Unions } \\
\text { Botswana, South Africa, Zimbabwe }\end{array}$ & 990 & 2,985 & 2,500 \\
\hline Total & 25,000 & 35,000 & 35,000 \\
\hline
\end{tabular}

Source: Ministry of Foreign Affairs 
Namibia is the African country with which Finland has had her longest and closest relations. Not that there have been many Finns directly engaged in Namibian affairs but Finnish missionaries have been active in Namibia for more than a hundred years and through their work Namibia has become widely known if not necessarily very well understood in Finland. To be sure, for a considerable time the knowledge was limited to the northern parts of the country which became known as Ambomaa (Ovamboland) and sometimes the interest took strange forms. At the end of the first world war it was suggested by some colonial enthusiasts in Finland that Ovamboland should be made a colony of Finland after the collapse of the German colonial empire. The suggestion was turned down by a more realistically-minded Secretary of State who observed later that "Finland would not have had any practical benefit form the country and the only consequence of our possessing it would have been the investment of considerable amounts of money in a country which we would have probably lost sooner or later anyway". 1) Interest waned and for decades the missionaries were left alone. But Ambomaa retained a place in

Finnish national consciousness and when new interest in Namibia was awakened in the $1960^{\prime} \mathrm{s}$ the old ties were rediscovered and new ones began to be built.

\section{The missionary factor}

Finnish missionaries are still in Namibia but their number has been in steady decline. Some ten years ago when the number was at its highest there were over a hundred Finnish missionaries in Namibia. At the beginning of 1980 the number had come down to 53 and in mid1981 it had shrunk to 25. The nature of missionary work has changed, too. The Finns no longer work independently but under the umbrella of the Evangelical-Lutheran Ovambo-Kavango church, an African church established in the late $1950^{\prime}$ s and responsible for church activities in Northern Namibia. All the Finns are engaged in educational, health, construction and technical maintenance work, in other words "in cooperation between churches or development cooperation of the churches" 2) and not in the evangelical work proper.

There are two main reasons for the decline of the number of Finnish missionaries in Namibia. Firstly, the Ovambo-Kavango Church which was established on the basis laid by Finnish missionary work is capable of taking over functions which have so far been fulfilled by the missionaries. Secondly, the war situation in Northern Namibia has made not only the 1ife of the Africans but also missionary work burdensome and dangerous. As the 1980 Annual Report of the Finnish Missionary Society complained, people working for the church have been killed and detained, communications have been cut, movements restricted and clinics closed. 3) In addition, some of the Finnish missionaries have been effectively deported from Namibia by the South African authorities who have refused to lengthen their visas. 
Finnish missionaries have, since their arrival in Namibia, been active in many fields. The first to create a written form for, and to translate the Bible into Ndonga, one of the main African languages in Northern Namibia was a Finnish missionary, Martti Rautanen. Almost all educational work in Northern Namibia was the responsibility of the missionaries until 1950's. Same is true of medical care. It was not until the $1960^{\prime}$ s that the South African authorities began to establish health facilities of their own. A strong cultural influence is revealed by the very Finnish-sounding Christian names of many present-day Namibians.

However, the relations between Finnish missionaries and Namibians have not been without problems. As a former missionary has written, "the attitude of the early missionary towards his congregation was patriarchal" and "are there any among us who have not been guilty of feeling of false superiority - or artificial comeraderie". 4) The missionaries, while by no means rich, have always been materially privileged compared with Africans and even able to hire African to work for them. In a segregated society social intercourse has not always been smooth and many embarrassing situations have occured. Politically the early missionaries were in sympathy with the colonial powers. The Finnish missionaries had smooth working relations with the South African authorities until the 1960's. When SWAPO was formed the first reaction among the missionaries was overwhelmingly negative.

Since then the whole body of the missionary opinion has changed. While at the beginning of the $1960^{\prime}$ s it was still debated in the newspaper of the Finnish Missionary Society Lähetyssanomat whether or not the Africans were ready for independence ten years later the paper "launched fierce attacks on the South African administration" in Namibia. 5) There appear to be two main reasons for this change. Firstly, most of Africa gained its independence in the early 1960's and the missionaries realised that this was bound to happen in the Southern parts of the continent, too. Second1y, a war began in Northern Namibia in 1966 and the warfare methods of the South African troops graphically revealed the nature of the South African state to the missionaries. When "victims from strange accidents, frightened people who were not even able to tell what had happened to them" began to appear at mission hospitals the missionaries realised that people were being tortured in detention. Since then, Finnish missionaries have "concretely understood that South Africa is a police state". But for all that, the missionaries are caught between two stools. They may feel sympathy for the aims of the Africans and detest the behaviour of South Africans but they have to work within the system which is a system operating on South Africa's terms. "The mission has believed that foreigners must be content to work on the conditions laid down by the prevailing rulers. Taking a stand is up to the inhabitants of the country."

The Official Position

Finland has adopted policies and taken positions on Namibia pre- 
dominantly within the framework of the United Nations system. During the last 15 years the Finnish state has grown gradually more active in the question of Namibia. When the United Nations General Assembly terminated the South African mandate and placed Namibia under direct UN control in 1966 Finland became one of the 14 members in the Ad Hoc Committee for South West Africa which was established to recommend practical means to administer the territory. While Finland was a member of the Security Council in 1969-70 the Finnish Ambassador Max Jakobson made many initiatives regarding Namibia. The 'advisory opinion' of the International Court of Justice in July 1971 that the continued occupation of Namibia by South Africa is illegal and South Africa "is under the obligation to withdraw its administration from Namibia immediately" was taken on the basis of a Finnish initiative in the Security Council. Establishement of the UN Fund for Namibia was based on a Finnish idea even though the form the Fund received was not exactly the one the Finnish had aimed at. Finland has been the only Nordic member of the Council for Namibia since its enlargement in 1974. The Nationhood Programme for Namibia com vering UN assistance to Namibia was established on the initiative of Finland and since the programme got underway its coordinators have been Finns. The UN Commissioner for Namibia since 1976 has been Martti Ahtisaari, previously Ambassador of Finland in Tanzania. Ahtisaari has combined the job of Commissioner with that of the Special Representative of the United Nations Secretary General for Namibia since this post was created in 1978 to take care of the execution of the Western-sponsored independence plan including elections which was endorsed by the UN Security Council in the now famous resolution 435. Finland has expressed her readiness to send peace-keeping troops to Namibia for the transition period and a Finnish battalion has been kept in readiness to leave at one month's notice.

The Finnish state has not always been so active. In the League of Nations Finland rarely had anything to do with the Mandate of South West Africa. After the second world war Finland was kept out of the new United Nations for ten years and when she finally became a member in 1955 she took an extremely cautious position on most matters and tried to keep out of all conflicts including the Namibian one. Gradually, the positions taken by Finland have changed too. Originally rather pro-South African viewpoints have progressively grown to more pro-SWAPO ones. In 1958 when the Finnish delegates for the first time participated in the discussions on Namibia in the General Assembly they explained that the relations between Finland and South Africa were most friendly and satisfactory and the participation of Finland in the activities of the Committee on South West Africa had taken place in a spirit reflecting these good relations.

More than ten years later in 1969 when the Security Council passed a resolution condemning South Africa for ignoring the earlier demands by the UN, Finland abstained in company with the big western powers United States, Britain and France. Even since then Finland has on certain occasions abstained from voting. During the $1970 \mathrm{~s}$ 
Finland began to vote for resolutions condemning South African actions and recognizing SWAPO as "the sole and authentic representative of the Namibian people in their struggle by a11 means, including the armed struggle". But Finland, together with other Nordic countries, has been at pains to express reservations on certain points mentioned in the resolutions, especially those concerning the legitimacy of armed struggle.

Changes have not only occured in the voting behaviour of the representatives of Finland. UN itself has changed as has the situation in Namibia. The resolutions and decisions of the world organisation have grown progressively more radical as the South African government has refused to comply with former demands by the UN. But there has been another change in the Finnish attitude too. Finland has endeavoured to discard its original passive role and become a mediator between the parties to the Namibian conflict and their supporters. For this purpose she has tried to negotiate and conciliate. As president Kekkonen put it in 1961 referring to Finnish actions in the United Nations in general, the Finns want to see themselves "as physicians ... rather than as judges... it is not for us to pass judgements nor to condemn; it is rather to diagnose and try to cure." 8) But it is because of the stubborness of South Africa that Finland has been practically forced to adapt a more pro-SWAPO attitude. There have been no major disagreements of this among the main political forces in Finland.

Faithful to her 'mediator' role Finland still maintains diplomatic relations with South Africa, Officially the relations are at a chargé d'affaires level but South Africa has given to its representative in Helsinki the rank of Ambassador. Contacts between Finland and South Africa date back to the time before the Finnish independence in 1917. Finland already had honorary counsuls in South Africa in the $1920^{\prime} \mathrm{s}$ although full diplomatic relations were not established until 1949. The successive Finnish governments have not heeded calls by solidarity movement in Finland to cut off the relations with South Africa. The explanations given have been that by maintaining relations there remains an opportunity to influence the policies of the South African government and in principle no country should be left outside of international cooperation. The protests have had a result, however, in that the contacts between Finland and South Africa are kept very low-key and occasional visits to and from South Africa receive little publicity.

Finland has diplomatic relations with South Africa but none with SWAPO. This is said to be because one of the basic principles in the Finnish foreign policy that Finland recognizes only states, not governments let alone would-be governments. The official attitude of the Finnish state to SWAPO is somewhat ambiguous. While Finland has in the UN voted for resolutions recognizing SWAPO as "the sole and authentic representative" of the Namibian people documents prepared by the Foreign Ministry in Finland characterize SWAPO only as "one of the most important representatives of the Namibian people people". The Finnish Foreign Ministry has had direct contacts with SWAPO only since 1970 and these have not taken place at the very highest level on the Finnish side. 
Assistance towards the Liberation of Namibia

\section{Governmental assistance}

Finland has backed her political commitments with a promise to take the future independent Namibia as one the main receiving countries in the (relatively small) Finnish foreign aid programme and by giving some assistance to various UN organs dealing with Namibia and, politically more significantly, directly to SWAPO. As in the Finnish development cooperation in general the Finnish state has been rather stingy and the sums involved have not been generous especially compared with those given by Sweden and Norway (see table on page 3). But the sums have not been neglible, either, and they have been rapidly increasing during the last few years. Total assistance by the government of Finland to Namibia and major organizations assisting Namibia is now at completely another level than some ten years ago as evidenced by table in appendix. Most of the aid has been allocated through various United Nations institutions like the Nationhood Programme.

SWAPO has received direct state aid from Finland since 1974. The share of this aid has varied between one third and one fourth of the total Namibia-related aid. The aid to SWAPO has been strictly humanitarian and to a considerable degree tied to use in Finland. The major part of the aid allocated to SWAPO has been used to provide scholarships for Namibian students sent by SWAPO to Finland. There were 27 such Namibians studying in Finland in mid-1981. Four of them were at universities; the rest at various vocational schools. The largest group of students were at the mechanical school of the Wärtsilä company in Turku. In addition, some of the aid has been given to SWAPO to buy medical and food assistance to refugee camps.

Non-governmental assistance

Aid by the Finnish state has been augmented not only by churches but also by other non-governmental organizations like solidarity groups, the student movement and the trade union movement. For want of resources, the material assistance from these organizations has been occasional and fairly small-scale but in view with the relative smallness of state aid, especially in the early 1970's, nongovernmental assistance has not been an insignificant contribution. Politically and morally it has certainly had an effect in raising the general level of awareness among the Finnish public and in offering a way to express political solidarity with SWAPO. The main actors in this field have been the National Union fo Finnish Students (SYL), the Central Organization of Finnish Trade Unions (SAK), the Finnish Africa Committee and the Peace Fund at the Finnish Peace Committee, the Solidarity Fund of the Social Democratic Party and the one-day voluntary work committee (Taksvärkki). 
$\underline{\text { Trade }}$

There is some trade between Finland and Namibia but it is impossible to gauge its extent besause some, probably most of it is done via South Africa. The officially registered trade between Finland and Namibia is rather insignificant as shown in Table but the trade between Finland and South Africa is much more extensive and some of it is known actually to come from of go to Namibia. The volume of the trade between Finland and South Africa has been increasing slowly but the proportion of the trade with South Africa in the total Finnish foreign trade declined from a rough1y 0.5 per cent in the 1960's and early 1970's to about 0.2 per cent in the late 1970 's. The trade with South Africa has been beneficial for the Finns because exports have been considerably larger than the imports.

Table 4

Trade between Finland and Namibia in 1960-62 and 1972-79 (in $1000 \mathrm{Fmk}$ )

\begin{tabular}{lrr}
\hline Year & Imports & Exports \\
\hline 1960 & 40 & 102 \\
1961 & n.i. & 149 \\
1962 & 22 & 74 \\
- & & \\
1972 & 1 & 40 \\
1973 & 53 & 31 \\
1974 & 114 & 237 \\
1975 & - & 12 \\
1976 & 1196 & 55 \\
1977 & 183 & 37 \\
1978 & 19 & 7 \\
1979 & 49 & 1 \\
\hline
\end{tabular}

Note: Imports from the country of origin, exports to the country of consumption

Source: Raimo Väyrynen, Suomen taloussuhteet Etelä-Afrikkaan ja Namibiaan (Finland's economic relations with South Africa and Namibia), Kimmo and Marja-Liisa Kiljunen (eds), Namibia viimeinen siirtomaa. Helsinki 1980, p. 213 and suomen virallinen tilasto.

The structure of Finnish-Namibian trade is similar to that of Finnish-South African trade. Finland exports products of the wood processing industries, mainly paper, and imports unprocessed com- 
modities like pelts and skins and occasionally considerable amounts of copper. The only known large consignment of imports from Namibia to Finland consisted of copper in 1974. Also some consumer goods are traded. According to a Finn who lived in Namibia, Finnish clothes (Vuokko), glassware (Iittala) and porcelain (Arabia) as well as stoves for sauna were available in the shops. In the business district in Helsinki one can see Swakara furcoats made of Namibian pelts displayed in shop windows. 9)

\section{Conclusion}

The Finns and the Namibians have come a long way in their relations. Namibia is for the Finns no more the distant Ambomaa with her curious people but a young African nation struggling for independence. Both the Finnish missionaries and the Finnish state have had to relinquish their former pro-South African attitudes and take a stand for the Africans. In spite of some ambiguities Finland is now committed to Namibian independence and SWAPO as the representative of the Namibian people. The state has backed its commitment by increasing substantially its aid to the activities of the UN in Southern Afirca and to SWAPO directly. State aid has been augmented by voluntary contributions from many civilian groups and movements, and the struggle of Namibians has certainly received support from the common Finns. Nevertheless, the actual amounts of aid have after all increases remained moderate. Further, Finland maintains official relations with the power occupying Namibia, South Africa, and trades Namibian natural resources with the South Africans. 


\section{References}

1. K.G. Idman, Maame itsenäistymisen vuosilta (When our country gained her independence). Porvoo 1953, p. 305-306.

2. Suomen lähetysseuran vuosikirja 1980 (The Annual Report of the Finnish Missionary Society 1980). Helsinki 1980.

3. Ibid., p. 71 .

4. Marja Väisälä, "Suomalainen lähetystyö" (Finnish missionary work), Kimno and Marja-Liisa Kiljunen (eds), Namibia - viimeinen siirtomaa (Namibia - the last colony), Helsinki 1980, p. 244. Much of this passage is based on Väisälä's article.

5. See Ari Kontro, "The Finnish Mission Society's Political Image of Africa", Scandinavian Journal of History 4, 1979, p. 38.

6. Väisälä, op. cit., p. 246-247.

7. Following passage is based main1y on Tapio Saarela, "Namibia Suomen ulkopolitiikassa" (Namibia in Finnish foreign policy) in Kimmo and Narja-Liisa Kiljunen (eds) op. cit., pp. 183-208 and various UN publications as well as personal communications from Foreign Ministry officials.

8. U1koasianministeriön julkaisuja. Yhdistyneiden Kansakuntien yleyleiskokouksen kolmas erityististunto sekä kuudestoista istuntokausi ja sen jatkoistunto. (Publications of the Ministry for Foreign affaris. The 3rd special session of the United Nations General Assembly and sixteenth session and it's resumed session) Helsinki 1962. p. 163.

9. For economic relations between Finland, South Africa and Namibia see Raimo Väyrynen, "Suomen taloussuhteet Etelä-Afrikaan ja Namibian" (Finland's economic relations with South Africa and Namibia), in Kimmo and Marja-Liisa Kiljunen (eds), op.cit., 209-229 and Suomen ulkomaankauppaliitto. Vienti - ja tuontitilasto. (The Finnish Foreign Trade Association. Trade Statistics) 1978, pp. 23 and 25,1979 p. 25. 


\section{FINLAND}

Table 5: The Assistance of the Government of Finland to Namibia and major Organizations assisting Namibia 1971-1981 (in $1000 \mathrm{Fmk}$ )

\begin{tabular}{|c|c|c|c|c|c|c|c|c|c|c|c|}
\hline & 1971 & 1972 & 1973 & 1974 & 1975 & 1976 & 1977 & 1978 & 1979 & 1980 & 1981 \\
\hline $\begin{array}{l}\text { UN Trust Fund } \\
\text { for Southern } \\
\text { Africa }\end{array}$ & 105 & 207 & 322 & 275 & 300 & 300 & 300 & 350 & 350 & 350 & 400 \\
\hline $\begin{array}{l}\text { UN Educational } \\
\text { and Training }\end{array}$ & & & & & & & & & & & \\
\hline Programme & 126 & 207 & 232 & 275 & 300 & 300 & 300 & 350 & 350 & 350 & 400 \\
\hline $\begin{array}{l}\text { UN Institute } \\
\text { for Namibia }\end{array}$ & - & - & - & - & - & - & 400 & 500 & 500 & 500 & 700 \\
\hline $\begin{array}{l}\text { Nationhood } \\
\text { Programme }\end{array}$ & - & - & - & - & - & - & - & - & 2000 & 2000 & 2000 \\
\hline $\begin{array}{l}\text { OAU Assistance } \\
\text { Fund }\end{array}$ & - & 100 & 109 & 130 & 150 & 150 & 150 & 200 & 200 & 200 & 200 \\
\hline Others & - & - & - & - & - & - & - & - & 29 & 530 & 855 \\
\hline Total & 231 & 476 & 721 & 860 & 1250 & 1217 & 1598 & 2386 & 5136 & 5920 & 7046 \\
\hline
\end{tabular}

1) Pledges

Sources: Finnish Foreign Ministry officials 

NORWAY

The Official Position

The official position of the Norwegian government on the Namibia question has been made clear in an number of policy documents and reflected in voting patterns at the United Nations and in other international fora. Sharp denunciation of the South African illegal occupation of Namibia, and calls for the withdrawal of South African military forces and administrative personnel from the territory have been actively supported by the government of Norway. The right to self-determination of the Namibian people is considered the only basis upon which a future non-racialist Namibia can be built.

Among political parties represented in Parliament there is a broad consensus on the question of Namibia. The differences of policy which may exist are those of nuances only, and relates to volume of assistance to SWAPO, modes of chanelling assistance etc. The one party which deviates from this general consensus is the Socialist Left Party. It favours a radical escalation of assistance to SWAPO including support for the armed struggle, and even unilateral sanctions against South Africa.

Assistance towards the 1iberation of Namibia

Governmental assistance

In conformity with its official policy the Norwegian government has supported SWAPO financially since 1972. All assistance is, however, restricted to humanitarian purposes according to principles laid down by Parliament.

From 1972 to date direct official assistance to SWAPO has progressively increased. A particularly sharp increase can be noted after 1977. In 1981 the commitment had reached the level of $10 \mathrm{mill}$. Norwegian kroner. For details see table in the appendix.

The figures refer to legally binding commitments, and it should be pointed out here that there has been a time lag in despersing the funds. The lag has in part been due to the lateness on the part of the Norwegian Parliament in making the commitments in each calendar year, and in part due to constraints at the receiveing end.

Additional government funds have been channelled indirectly to SWAPO and Namibians through non-governmental organizations, notably the Norwegian Students' and Teachers' International Assistance Fund; Church of Norway - Council on Foreign Relations; the Namibia Association at Elverum. Furthermore contributions have been made to the Educational Programe of UNHCR to the order of $8 \mathrm{mill}$. Norwegian kroner in 1980; to the UN Educational and Training Programme to which the cumulative contribution for the years 1976-80 amounted to 15.5 mi11. Norwegian kroner; and until 1980 to the International 
University Exchange Fund (IUEF) for fellowships to students from southern Africa. Subsequent to the Craig Williamson spy affair and the dismantling of IUEF, however, these funds are now being channelled via the World University Service (WUS) in Geneva and the Africa Educational Trust in London. This type of contributions are made to general programmes which are rather broad in scope, sometimes worldwide or covering the whole of the southern African region. As such these funds will not benefit Namibians only, but it should be emphasized that a significant proportion is allocated to educational programmes for Namibian students.

The contributions towards meeting the costs of the operation of the UN Institute for Namibia were initiated in 1976 and reached a total of $1.2 \mathrm{mil1}$. Norwegian kroner in 1981. Details of commitments over the period 1976-81 can be found in table in the appendix.

Non-governmental assistance

Solidarity organizations, notably the Norwegian Council for Southern Africa and the Namibia Association at Elverum have been active in supporting SWAPO in various ways. The former has for a great number of years been involved primarily in information work on the liberation struggle in Namibia by way of producing written material and organizing public meetings and conferences, but has also collected funds from the general public to be placed at SWAPO's disposal, as we11 as acted as a pressure group on the Norwegian government in Namibian matters. The latter is a recently formed organization whose activities are restricted geographically to Elverum, a small town in eastern Norway.

In its brief history, however, the Namibia Association has managed to mobilize virtually the entire local community in an impressive effort to collect clothes, bicycles; to produce writing pads and protein biscuits; and to disseminate information on the liberation struggle in Namibia. In its first year the association is believed to have collected the equivalent of $4 \mathrm{mill}$. Norwegian kroner. In recognition of this massive manifestation of solidarity with the people of Namibia SWAPO President Sam Nujoma visited Elverum in August 1981 .

\section{Trade}

Notwithstanding the official position adopted by the government, commercial and shipping links are still maintained between Norway and Namibia at a non-governmental leve1.

Although the exchange of goods between the two countries is very $1 \mathrm{imited}$, it nevertheless exists as can be seen from the following table: 
Table 6

Norway's, Trade with Namibia 1970-80. (Imports c.i.f. and exports f.o.b. in current prices). In 1000 Norwegian kroner.

\begin{tabular}{lrr}
\hline Year & Imports & Exports \\
\hline 1970 & 865 & 2,160 \\
1971 & 2,156 & 566 \\
1972 & 1,867 & 725 \\
1973 & 361 & 1,107 \\
1974 & 1,593 & 1,330 \\
1975 & - & 608 \\
1976 & 120 & 452 \\
1977 & 25 & 133 \\
1978 & 109 & 94 \\
1979 & 60 & 702 \\
1980 & 330 & 11,145 \\
\hline
\end{tabular}

Sources: Month1y Bulletin of External Trade, December 1971-80, Central Bureau of Statistics, Oslo.

Considering the limited nature of this trade relation, its significance is, therefore, political rather than economic. The sudden increase in exports in 1980, however, warrants an explanation. It appears that $10.77 \mathrm{mill}$. kroner of the total figure derive from exports of ships exceeding 100 gross tons, most probably a fishing vessel. Otherwise exports to Namibia consist in the main of processed fish products and instruments of measurement and analysis. Imports consist of unprepared pelts and precious stones.

Shipping 1 )

As one of the world's major shipping nations Norway has been, and is most 1ikely still, involved in shipment of goods to and from $\mathrm{Na}^{-}$ mibia. It has been conclusively established that Norwegian ships have been carrying copper ores from Walvis Bay to Hamburg in West Germany on a regular basis. Among the ships involved on this route in the period 1976-78 are "Blix" owned by the shipping company L. Gi11-Johannessen \& Co., Oslo; "Bajka" and "Balao" of Torvald Klaveness \& Co. A/S; "Havbjфrn" and "Havkatt" both owned by A/S Havtor. The latter company has also carried large quantities of oil to South Africa.

A number of Norwegian oil tankers have also called at Walvis Bay. It has not been ascertained, however, whether oil has been unloaded or the reason for berthing has been taking in supplies or bunkers 
etc. Two ships, the "Tigre" of Wilhe1m Wilhe1msen A/S and "Beaumont" of Bjфrnstad Ship Owners, were laid up in Walvis Bay harbour from April to September 1980 and April to May 1980 respectively.

These shipping activities clearly contravene Decree No. 1 of the UN Council for Namibia on extraxtion, processing and transportation of Namibian raw materials. Confronted with these facts the Norwegian Ministry of Foreign Affairs has stated that, in the absence of a decision by the Security Council binding on all UN member states (Decree No. 1 does not have the same legal status it is claimed), Norwegian ship owners have thus not violated Norwegian law, but clearly acted against official government policy in this matter.

In line with the trend in international shipping Norwegian ship owners increasingly register their ships under so-called "flags of convenience", e.g. in Liberia, Panama. 2) It may well be, therefore, that Norwegian shipping interests are more heavily involved in carrying goods to and from Namibia than meets the eye at a superficial glance. The above information refers to ships registered in Norway only.

\section{Conclusion}

In summing up there can be no doubt that the Norwegian government strongly condemns the illegal occupation of Namibia by South Africa, and energetically supports the liberation struggle in the territory under SWAPO leadership, politically and materially. Non-governmental and solidarity organizations have added on to this support for the struggle.

On the other hand, commercial and shipping connection still persist which implies collaboration with the illegal occupying South African regime - however insignificant these connections may seem in purely economic terms.

There is, however, no indication that the Norwegian government will take unilateral action in respect of sanctions against South Africa, and thus by necessity also against Namibia. In a recent statement before Parliament the minister of foreign affairs elaborated at length on the matter of unilateral sanctions against South Africa, and conlcuded that no such action would be taken at this juncture. 3) A detailed study has already been undertaken by the ministry of foreign affairs on the possible effects on the Norwegian economy of unilateral sanctions against South Africa. Its deliberations and conclusions remain donfidential, however.

It is conceivable, though, that the government might embark on a sanctions policy, short of a mandatory resolution by the UN Security Council, if joined by the other Nordic countries and preferably also members of the vaguely defined group of 'like-minded' countries, e. 8. Holland. Whether or not this will actually happen, will depend 
in some measure on the consultations in fora of the UN, but more importantly on the developments in the southern African sub-region and on pressures exerted on the government of the respective abovementioned countries by political parties, solidarity organizations and the general public. If it were to materialize such a limited multilateral action would most certainly be felt by the South African economy, and not least have a political impact on the world community.

\section{Notes}

1. Information on calls and carriage of Namibian goods in this section has been taken from фystein Gudim, Vår vanaere og vår makt, Afrika-informasjon, (10), No. 4, 1980, p. 13.

2. For further details see Uteregistrering av skip og Skipsfartens egenkapital (NOU 1980:45)!

3. Forhandlinger i Stortinget (Parliamentary Debates), No. 177 (1980-81), 18 March 1981, pp. 2724-6. 
NORWAY

Table 7

Commitments of Direct Official Norwegian Assistance to SWAPO 1972-81 (1 000 Norwegian kroner)

\begin{tabular}{lc}
\hline Year & Amount \\
\hline 1972 & 16 \\
1973 & 100 \\
1974 & 100 \\
1975 & 1,000 \\
1976 & 1,500 \\
1977 & 4,000 \\
1978 & 7,000 \\
1979 & 8,000 \\
1980 & 8,000 \\
1981 & 10,000 \\
\hline
\end{tabular}

Source: Ministry of Foreign Affairs, 0s1o

Tab1e

Commitments of Official Norwegian Assistance to the UN Institute for Namibia 1976-81 (1 000 Norwegian kroner)

\begin{tabular}{lc}
\hline Year & Amount \\
\hline 1976 & 300 \\
1977 & 500 \\
1978 & 750 \\
1979 & 900 \\
1980 & 1,000 \\
1981 & 1,200 \\
\hline
\end{tabular}

Source: Ministry of Foreign Affairs, 0s10 
SWEDEN

\section{The Official Position}

From a variety of public statements Sweden's international stance regarding Namibia could be summarised thus: The United Nations has sovereignty over Namibia, and SWAPO is the most representative spokesman of the people of Namibia. South Africa is occupying the territory illegally and attempting to liquidate SWAPO internally as we11 as damage the movement's external support through aggressive actions against Angola, Mozambique and Zambia. By seeming to take part in the negotiotions for Namibian independence, South Africa is shielding itself from international sanctions. And by delaying these negotiotions the regime gains time both to sabotage work towards real independence for Namibia and to implement its own policies in the territory. The argument that international action against South Africa would hinder the Namibia negotiations is therefore rejected. On the contrary, such action may be the prerequisite for their success. Sweden believes that delays only increase the risk for widespread bloodshed, and in order to ensure the implementation of the UN plan, the Security Council should decide on effective measures. Such measures could be an oil embargo, an air boycott or other selective sanctions. The people of Namibia have a right to self-determination and Sweden supports SWAPO's call for the release of all political prisoners and the withdrawal of South Africa's armed forces.

For more than a decade Sweden has urged that comprehensive economic sanctions within the framework of the UN Security Council be put into effect to compe1 changes in South Africa.

Within the Swedish parliament there is broad agreement among all political parties on the southern African policy, and this also applies to assistance given to SWAPO. On 1 July 1979 Sweden's 1aw on Prohibition of Investments in South Africa and Namibia came into force. This unilateral action was taken partly to express solidarity with black organisations calling for the isolation of South Africa and partly to encourage other nations (ultimately also the Security Council) to decide on similar measures against the regime. The law generally prohibits Swedish companies making investments in South Africa and Namibia and prevents those companies already present from expanding. Exemptions are thus allowed for certain replacement in vestments. According to the law these rules should be applied restrictively. The 1 aw was acclaimed internationally and undoubtedly increased coodwill towards Sweden in Africa while Swedish industries which largely opposed the introduction of the new law, now use the fact of it to promote sales in independent Africa.

Soon after Sweden passed the law on prohibition of investments Holland announced that it was considering similar action. This has not yet led to anything definite. However, in June 1980 the Dutch Parliament demanded that the government unilaterally impose an oil 
embargo on South Africa. The Dutch government replied that it would only do so on condition that the Nordic countries were partner to the action. Questioned on Sweden's willingness to partake in such action Foreign Minister 0la U1lsten referred to the fact that the UN Security Council had not decided upon sanctions, which is a traditional Swedish prerequisite for taking part in such action. He added that Sweden participating with a limited circle of countries could not accomplish an oil embargo against South Africa. It was for each country to choose the measures best suited to its own circumstances, he said, and such measures should, of course, involve an area of some substance in its relations with South Africa.

\section{Assistance towards the liberation on Namibia}

\section{Governmental assistance}

Sweden's support to SWAPO is humanitarian and is directed only towards the liberation movement's civilian work in the form of assistance to refugees (primarily clothing, provisions, medical equipment and vehicles), education, information work and contributions towards SWAPO's administrative costs. Sweden recognises that the people of Namibia have been driven to armed struggle, but this struggle is not given official aid.

Apart from direct aid to SWAPO channelled through the Swedish International Development Agency SIDA, Swedish assistance is disbursed through various non-governmental and intergovernmental organizations such as UNHCR, the Red Cross, the International Defence and Aid Fund, World University Service, church organizations and solidarity movements.

Aid to SWAPO increased rapidly throughout the $70^{\prime} \mathrm{s}$. In 1974/75 SWAPO received 1,2 million $\mathrm{kr}$. By $1977 / 78$ it had risen to 14,5 million $\mathrm{kr}$ and the sum granted for $1980 / 81$ is 33 million kronor.

SIDA foresees that the situation in southern Africa will probably lead to a need for increased assistance to refugees from Namibia and South Africa.

Should Namibia achieve independence, Sweden will draw upon the resources of its Emergency Fund to facilitate immediate large-scale assistance (Some $400 \mathrm{million}$ kronor is available in the Fund for $1981 / 82$.

\section{Non-governmetal assistance}

A number of non-governmental organizations in Sweden are involved in solidarity activities. A SWAPO delegation visited Sweden during the last general elections as guests of the Social Democrats to study the Swedish electoral system. The Swedish labour movement LO has also been conducting trade union work within Namibia, and the 
co-ordinating body for Swedish labour-movement contacts with third world countries, AIC, is helping SWAPO prepare for the possibility of elections in Namibia.

The Lutheran Church aid section "Lutherhjä1pen" is involved in several activities. Only last month (February -81) Lutherhjälpen and its Scandinavian sister organizations sent 67 tons of neccessities to SWAPO's refugee camps in Zambia and Angola. Worth about 2 million kronor, these included 500 large tents, 15 tons of enriched foods, other foodstuffs, blankets and medical supplies. Inside Namibia Lutherhjälpen gives support to all those churches working for change. It has built a study center for the Ovambo Kavango church, and supplied the ill-fated church printing press at Oniipa which has twice been sabotaged by bombing.

The printing press is now being rebuilt with assistance from Lutherhjälpen and in all 900000 kronor has already gone to this project. In Sweden Lutherhjälpen also acts as a pressure group on the government. In a recent statement the organization's board declared that all investments by foreign companies in South Africa and Namibia were investmnets in apartheid - while such investments might improve the economic situation of a few workers they nevertheless helped to maintain and strengthen the widespread oppression. Lutherhjä1pen called on the Swedish government to therefore show the greatest restraint in granting requests for dispensations from Swedish companies in South Africa.

If these companies managed to circumvent the law on Prohibition of Investments then this piece of legislation should be overhauled, the board said.

Lutherhjälpen believes there is an urgent need for the government to investigate the role of Swedish companies in South Africa's armaments build up.

Another large current programme of assistance to SWAPO is being conducted by the solidarity organizations AGIS, ISAK and Brödet och Fiskarna. The 1,8 million $\mathrm{kr}$ project of which 1,4 million $\mathrm{kr}$ has been given by SIDA started on Namibia Day 1980 (26 August), is to provide medical necessities to the Kwanza Sul refugee camp in Angola, which has a population of more than 20000 people. The camp is situated on an old coffee plantation in central Angola and the former residences now serve as the camp's hospital. The Swedish solidarity organizations are planning to extend their project and build a 1,5 million $\mathrm{kr}$ hospital for the camp. Medical personnel recruited by Afrikagruppernas rekryteringsorganisation (ARO) are already working at Kwanza Sul.

AGIS has also run several general compaigns together with the Southern African liberation movements (ZAPU, ZANU, SWAPO and ANC) to collect funds and clothing for refugees. 
AGIS has together with Isolera Sydafrika Kommittén (ISAK) strongly opposed requests from some Swedish companies in South Africa to be exempted from the law prohibiting investments in South Africa. They are calling on the government to make preparations for the total isolation of South Africa.

Brödet och Fiskarna, a working collective, has collected more than 250 tons of clothing for southern African refugees since 1974. Transport costs to Africa have been paid by SIDA. B \& F has also collected tools, radios, tape-recorders, typewriters, toys and household goods for the liberation movements. It donates ca $75000 \mathrm{kr}$ medical equipment annua11y.

Since 1978 the Centre Party Youth League has run a spring campaign during which information about Namibia is distributed and money is raised through a variety of activities to assist SWAPO with its education work. Last year nearly $120000 \mathrm{kr}$ was raised.

In December 1980 "Svenska Folkhögskoleelevers Förbund" and the gymnasium students "Elevförbundet" began a joint two-year programme to raise money to print schoolbooks for Namibian refugee children.

Other groups involved in assisting Namibian exiles include Emmaus (which has been supplying goods for ten years) and the Swedish Baptist Youth. The above information reflects only the larger solidarity projects and is by no means exhaustive.

\section{Trade}

There appears to be no easy access to detailed information of Swedish trade with Namibia. Furthermore, it is obvious that trade in Namibian goods can easily appear statistically as trade with South Africa. Information released by the Department of Statistics gives the broad categories of goods involved and indicates a relatively low volume of trade. None of this trade is at governmental level.

Table 8

Sweden's trade with Namibia 1974 - 1980 in Skr millions

\begin{tabular}{|c|c|c|c|}
\hline Year & Imports & Exports & \\
\hline 1974 & 2.4 & 2.4 & \\
\hline 1975 & 2.3 & 0.5 & \\
\hline 1976 & 3.0 & 0.4 & \\
\hline 1977 & 3.6 & 0.2 & \\
\hline 1978 & 3.3 & 0.4 & \\
\hline 1979 & 3.9 & 0.1 & 0,1 \\
\hline 1980 & 4.13 .9 & 1.0 & 1.0 \\
\hline 1980 Jan-May & 0.72 .9 & 0.1 & o. \\
\hline
\end{tabular}


Source: Department of Trade, Stockholm

The Central Bureau of Statistics describes the 1974-76 imports as being primarily untreated (obehandlad) hides and skins. In 1977 ore and base metals constituted Skr 2 million of imports and in 1979 they constituted $\mathrm{Skr} 1.1$ million of imports. The remaining expenditure is again mainly attributed to hides and skins.

Exports form 1974-1979 consisted of manufactured and semi-manufactured machinery. Exports in 1980 included paper and pulp.

The figures for January to December 1979 are shown here as a more detailed indicator:

Table 9

Imports from Namibia in $1000^{\prime} \mathrm{s}$ of Swedish kronor

Fruit and vegetables 49

Unprepared pelts and furs

2718

Ore and metal 1107

Other animal and vegetable raw mat. 20

Rubber goods

total

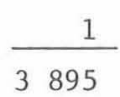

Exports to Namibia in $1000^{\prime} \mathrm{s}$ of Swedish kronor

Metal goods 27

Metalworking equipment

other non-electrical machines and applicances

Sanitary, piping, heating and lighting installation materials 7

other finished products

tota1

$\frac{10}{100}$

According to trade statistics and official statements Sweden does not buy uranium from Namibia. Swedish importers of uranium have stated they have no intention of buying uranium from Namibia. However, some researchers claim that uranium from Namibia, Gabon and Niger, mixed in France, finds its way inter alia to Sweden.

\section{Conclusion}

Compared with the other Nordic countries, Sweden's official position is more outspoken, and indeed her direct actions (in terms of aid and the law prohibiting investments in South Africa and Namibia) go further than those of Norway, Finland and Denmark. 

SWEDEN

Table 10

Programme in Zambia

Contribution in cash

$147000 \mathrm{kr}$

Transport

$933500 \mathrm{kr}$

Medica1 equipment

$228000 \mathrm{kr}$

Foodstuffs

$728000 \mathrm{kr}$

Agricultural equipment

$85000 \mathrm{kr}$

Social welfare

$47000 \mathrm{kr}$

Information

$170000 \mathrm{kr}$

Emergency fund

$614500 \mathrm{kr}$

Reserve

$22000 \mathrm{kr}$

Programme in Tanzania

Total $2975000 \mathrm{kr}$

Foodstuffs, clothing

$56000 \mathrm{kr}$

Warehouse

$14000 \mathrm{kr}$

Programme in Botswana

$70000 \mathrm{kr}$

Foodstuffs and transport

$45000 \mathrm{kr}$

Programme in Angola

Contribution in cash

$125000 \mathrm{kr}$

Transport

$1075000 \mathrm{kr}$

Office equipment

$18212 \mathrm{kr}$

School equipment

$250000 \mathrm{kr}$

Foodstuffs

$1070320 \mathrm{kr}$

Emergency fund

$120000 \mathrm{kr}$

Reserve

$41468 \mathrm{kr}$

Programme in Stockholm

Total $2700000 \mathrm{kr}$

Office equipment

$65000 \mathrm{kr}$

Grant to representative

$35000 \mathrm{kr}$

Emergency fund

$10000 \mathrm{kr}$

Total $110000 \mathrm{kr}$ 
The Scandinavian Institute of African Studies in Uppsala was started in 1962 as an element in the initial Scandinavian collaboration to collect and disseminate information about Africa and to promote a scholarly exchange of ideas on topics of central concern to the developing countries.

The Institute's task is to circulate information about Africa to public institutions, private organizations and individual inquirers in the Scandinavian countries. This is done through library and publication work and through educational activities of various kinds.

Research activities. Another of the Institute's principal tasks is to stimulate and support Scandinavian research on Africa. Several research workers are associated with the Institute and travelling scholarships are distributed annually to forward research in Africa.

The library. The library specializes mainly in material on modern Africa. Endeavours are made to stock the current literature on the social sciences, modern history and modern biography. There are complete catalogues, both of the Institute's own book stock and of the stocks of Africana in all the major Scandinavian scientific libraries.

Seminars and courses. Once a year the Institute organizes an international seminar in which specialists from all over the world are assembled for lectures and discussions. The seminar proceedings are published in one of the Institute's publication series.

The Institute also arranges courses for teachers and other persons dealing with information on Africa. Both Scandinavian and non-Scandinavian experts are engaged to lecture on Africa and African problems. In many cases lecture tours are arranged, covering several of the university towns in Scandinavia.

The Institute does not provide any instruction for those aiming at academic degrees.

For more detailed information about the activities of the Institute, we recommend the reading of the annual Newsletter which can be ordered from the Institute free of charge.

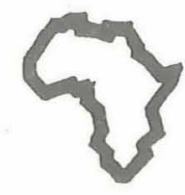

The Scandinavian Institute

of African Studies

P.O. Box 2126

S-750 02 UPPSALA, Sweden 